\title{
OPTIMAL AGE-REPLACEMENT POLICY FOR NON-REPAIRABLE TECHNICAL OBJECTS WITH WARRANTY
}

\section{OPTYMALNA STRATEGIA WYMIAN WEDŁUG WIEKU OBIEKTÓW TECHNICZNYCH NIENAPRAWIALNYCH Z GWARANCJĄ*}

\begin{abstract}
This paper investigates the effects of introducing preventive replacement to maintenance system implemented by age-replacement of technical objects with valid manufacturer's warranty and non-repairable. In order to examine this, the cost per unit time, resulting from the use of the preventive replacements and repairs system is investigated. The function expressing the cost depending on the time of replacement is defined on the basis of the foundations of the theory of semi-Markov processes. Sufficient conditions for the existence of the minimum of criteria function were formulated, in this case when the failure rate function is increasing. In the final part of the paper, a numerical example illustrating the findings of the paper was presented.
\end{abstract}

Keywords: age-replacement, semi-Markov process, cost per time unit, warranty, IFR class, failure rate function.

\begin{abstract}
W pracy bada się efekty wprowadzenia odnów prewencyjnych do systemu eksploatacji, realizowanych przez wymiany wedlug wieku obiektów technicznych posiadajacych gwarancje producenta i nienaprawialnych. W tym celu bada się koszt przypadajacy na jednostkę czasu, wynikający $z$ wykonywanych $w$ systemie eksploatacji wymian profilaktycznych i napraw. Funkcję wyrażająca ten koszt w zależności od czasu wymiany zdefiniowano w oparciu o podstawy teorii procesów semi-Markowa. Sformulowano warunki dostateczne istnienia minimum kosztu wymian w przypadku, gdy czas do uszkodzenia ma niemalejąca funkcję intensywności uszkodzeń. W końcowej częśsi artykułu przedstawiono przykład numeryczny ilustrujący przedstawione w pracy wyniki.
\end{abstract}

Stowa kluczowe: wymiana wedlug wieku, proces semi-Markowa, koszt na jednostkę czasu, gwarancja, klasa rozkładów IFR, funkcja intensywności uszkodzeń.

\section{Introduction}

In order to obtain maintenance system reliability and availability, preventive replacements according to the age of elements and subsystems are introduced into the maintenance system. Age-replacements have been known for a long time, e.g. [2]. This problem was examined through development of preventive age-replacement for various individual cases. In particular, in the papers $[3,4,10,12]$ whole range of important analytical results was obtained. However, the methods of age-replacement for technical objects with valid manufacturer's warranty were developed much later. Currently, manufacturer's warranty is a basic element of modern market. The basic role of a warranty is an offer including a list of actions the customer must undertake when the product is damaged during warranty period. Manufacturer's warranty for the product creates an incentive for the customer to make various commitments, improving the reputation of the manufacturer, and influencing the market share as well as potential profit. A detailed discussion and overview of the results connected to various approaches to product warranty is included in the following papers $[5,6$, 7]. In particular, the warranty policy for non-repairable products was discussed in the paper [5]. The warranty policy analyzed in this paper is carried out through the strategy of damaged element replacement within the period of warranty by a new element with full warranty. The mathematical model and cost analysis for such strategy were developed in the papers $[1,8,13]$. In the paper $[14]$ the criteria function defining the costs connected to carrying out preventive replacements of non-repairable elements with a warranty when time before failure has distribution with increasing failure rate function. In the quoted paper the criteria function depends on the distribution of time before failure, repair and preventive replacement costs as well as the length of warranty period. It is assumed that the times of repair and preventive replacement are negligible. In this paper the criteria function discussed is more general than in the paper [14], taking into consideration non-zero times of repair and times of preventive replacements. The set-up of the criteria function $\mathrm{g}(\mathrm{x})$ was based on the limit values of semi-Markov processes. The aim of this work is to formulate the conditions for existence of minimum function $\mathrm{g}(\mathrm{x})$ defining losses in maintenance system.

\section{Basic symbols and definitions}

In this paper the following symbols are used:

$\mathrm{S}_{1}$ - state of proper work,

$\mathrm{S}_{2}$ - state of repair (replacement) during warranty period,

$\mathrm{S}_{3}$ - state of preventive replacement during warranty period,

$\mathrm{S}_{4}$ - state of repair (replacement) after warranty period,

$\mathrm{z}_{2}$ - cost of repair (replacement) per time unit during warranty period,

$\mathrm{z}_{3}$ - cost of preventive replacement per time unit,

$\mathrm{z}_{4}$ - cost of repair (replacement) per time unit after warranty period,

$\mathrm{w}$ - length of warranty period,

$\mathrm{T}_{1}$ - lifetime of technical object (time before failure),

$\mathrm{T}_{2}$ - length of repair (replacement) time during warranty period,

$\mathrm{T}_{3}$ - length of preventive replacement time after warranty period,

(*) Tekst artykułu w polskiej wersji językowej dostępny w elektronicznym wydaniu kwartalnika na stronie www.ein.org.pl 
$\mathrm{T}_{4}$ - length of repair (replacement) time after warranty period, $\mathrm{ET}_{\mathrm{i}}-$ mean value for random variable $\mathrm{T}_{\mathrm{i}}, \mathrm{i}=1,2,3,4$, $\mathrm{x}$ - (preventive) replacement age of technical object (element), $\mathrm{f}(\mathrm{t})$ - density of probability for lifetime random variable $\mathrm{T}_{1}$, $\mathrm{F}(\mathrm{t})$ - distribution function for random variable $\mathrm{T}_{1}, \mathrm{~F}(\mathrm{t})=\mathrm{P}\left\{\mathrm{T}_{1}<\mathrm{t}\right\}$, $\mathrm{R}(\mathrm{t})$ - reliability function for random variable $T_{1}, \mathrm{R}(\mathrm{t})=1-\mathrm{F}(\mathrm{t})$, $\lambda(\mathrm{t})$ - failure rate function for time $\mathrm{T}_{1}, \lambda(\mathrm{t})=\mathrm{f}(\mathrm{t}) / \mathrm{R}(\mathrm{t})$,

$\mathrm{g}(\mathrm{x})$ - criteria function defining loss per time unit depending on replacement time $\mathrm{x}$.

In the paper [14] it was shown that if at moment $x$ preventive replacement is carried out, the cost per time unit is given in formula:

$$
g(x)=\left\{\begin{array}{lll}
\frac{c_{p} R(w)+c_{d} F(x)}{E T(x)}, & \text { for } & w \leq x, \\
\frac{c_{p} R(x)+c_{d} F(x)}{E T(x)}, & \text { for } & w>x,
\end{array}\right.
$$

where: $c_{d}$ stands for cost of replacement of damaged element, $c_{p}$ stands for cost of purchase of the element with $\mathrm{ET}(\mathrm{x})$ the integral in the form of:

$$
E T(x)=\int_{0}^{x} R(s) d s
$$

Function $\mathrm{g}(\mathrm{x})$ determined by formula (1) is continuous for $\mathrm{x} \geq 0$ and differentiable for $\mathrm{x} \neq \mathrm{w}$. In the paper [14] final sufficient conditions were given for which function $\mathrm{g}(\mathrm{x})$ has a minimum. In the age-replacement model presented in the paper, neither the times of replacements nor times of preventive replacements are given. The semi-Markov model built in the paper takes into consideration times of replacements as well as exchanges and is based on the limit theorem for semi-Markov processes with finite number of states [9]. One of the assumptions of this theorem is the requirement for mean values $\mathrm{ET}_{\mathrm{i}}, \mathrm{i}=1,2,3,4$ of times $\mathrm{T}_{\mathrm{i}}, \mathrm{i}=1,2,3,4$ remaining at states to be positive. In the semi-Markov model the criteria function $\mathrm{g}(\mathrm{x})$ belongs to the distribution of probability of random variable depends on $T_{1}$, mean values $\mathrm{ET}_{\mathrm{i}}, \mathrm{i}=1,2,3,4$, unit costs $\mathrm{z}_{\mathrm{i}}, \mathrm{i}=1,2,3,4$ as well as limit probabilities $\mathrm{p}_{\mathrm{i}}^{*}(\mathrm{x}), \mathrm{i}=1,2,3,4$ of Markov chain embedded in semi-Markov process $X(t)$. It is known that $[9,11]$ criteria function $\mathrm{g}(\mathrm{x})$ expressing repair and replacement costs has the following form:

$$
g(x)=\frac{\sum_{i=1}^{4} z_{i} E T_{i} p_{i}^{*}(x)}{\sum_{i=1}^{4} E T_{i} p_{i}^{*}(x)}
$$

where $z_{i}$ is the unit cost of technical object remaining at state $S_{i}$, and $\left.\mathrm{p}_{\mathrm{i}}{ }^{*} \mathrm{x}\right)$ is the limit probability of Markov chain embedded in semiMarkov process assuming that at moment $\mathrm{x}$ preventive replacement takes place. The following deliberations assume $\mathrm{z}_{1}=0$.

\section{Mathematical model of the problem}

The paper presents the possibility of an approach to building criteria function $\mathrm{g}(\mathrm{x})$ different than in other known papers. This approach is based on the limit property of semi-Markov processes for building criteria function. In order to build such a model, four states of $\mathrm{S}_{1}, \mathrm{~S}_{2}$, $\mathrm{S}_{3}$ and $\mathrm{S}_{4}$ of semi-Markov process $\mathrm{X}(\mathrm{t})$ have been delineated.

On the basis of defining conditions for the states $S_{1}, S_{2}, S_{3}, S_{4}$ the matrix $\mathrm{P}$ of probabilities of embedded Markov chain may be written as follows

$$
P=\left[\begin{array}{cccc}
0 & p_{12}(x) & p_{13}(x) & p_{14}(x) \\
1 & 0 & 0 & 0 \\
1 & 0 & 0 & 0 \\
1 & 0 & 0 & 0
\end{array}\right],
$$

where $\mathrm{x}$ is the age of replacement. Conditional probabilities jest $\mathrm{p}_{1 \mathrm{i}}(\mathrm{x})$, $\mathrm{i}=2,3,4$ are defined separately for cases $\mathrm{x}<\mathrm{w}$ and $\mathrm{x} \geq \mathrm{w}$. The first case to be examined is when $\mathrm{x}<\mathrm{w}$. If replacement time $\mathrm{x}<\mathrm{T}_{1}$, the repair took place during warranty period (stage $\mathrm{S}_{2}$ ), thus:

$$
\mathrm{p}_{12}(\mathrm{x})=\mathrm{F}(\mathrm{x}) \text {. }
$$

If $x \geq T_{1}$, then during warranty period the preventive replacement is carried out (state $\mathrm{S}_{3}$ ), thus:

$$
\mathrm{p}_{13}(\mathrm{x})=\mathrm{R}(\mathrm{x})
$$

In the case when $\mathrm{x}<\mathrm{w}$, then, for post-warranty repair $\left(\right.$ state $\left.\mathrm{S}_{4}\right)$ it is:

$$
\mathrm{p}_{14}(\mathrm{x})=0 .
$$

For $\mathrm{x} \geq \mathrm{w}$ repair is carried out when $<\mathrm{T}_{1}$, thus:

$$
\mathrm{p}_{12}(\mathrm{x})=\mathrm{F}(\mathrm{w}) .
$$

If $\mathrm{T}_{1} \geq \mathrm{x}$, preventive replacement is carried out, thus:

$$
\mathrm{p}_{13}(\mathrm{x})=\mathrm{R}(\mathrm{x})
$$

Repair after warranty period is carried out if $\mathrm{w} \leq \mathrm{T}_{1}<\mathrm{x}$, thus:

$$
\mathrm{p}_{14}(\mathrm{x})=\mathrm{F}(\mathrm{x})-\mathrm{F}(\mathrm{w})
$$

It is easy to confirm that in both cases discussed here for matrix (4) the following:

$$
\mathrm{p}_{12}(\mathrm{x})+\mathrm{p}_{13}(\mathrm{x})+\mathrm{p}_{14}(\mathrm{x})=1 .
$$

It is known that [9] limit probabilities $\mathrm{p}_{\mathrm{i}}{ }^{*}(\mathrm{x}), \mathrm{i}=1,2,3,4$ in formula (3) are obtained as solution of linear equation system in the form of:

$$
\sum_{i} p_{i}^{*}(x) p_{i j}=p_{j}^{*}(x), \text { where } \mathrm{j}=1,2,3,4
$$

The above system of equations is a dependent system, which is why one of the equations is replaced by normalization condition in the form of:

$$
\sum_{i} p_{i}^{*}(x)=1
$$

For $\mathrm{x}<\mathrm{w}$ a system of equations is solved in the form of:

$$
\begin{gathered}
\mathrm{F}(\mathrm{x}) \mathrm{p}_{1}{ }^{*}(\mathrm{x})=\mathrm{p}_{2}{ }^{*}(\mathrm{x}), \\
\mathrm{R}(\mathrm{x}) \mathrm{p}_{1}{ }^{*}(\mathrm{x})=\mathrm{p}_{3}{ }^{*}(\mathrm{x}), \\
\mathrm{p}_{4}{ }^{*}(\mathrm{x})=0 \\
\mathrm{p}_{1}{ }^{*}(\mathrm{x})+\mathrm{p}_{2}{ }^{*}(\mathrm{x})+\mathrm{p}_{3}{ }^{*}(\mathrm{x})+\mathrm{p}_{4}{ }^{*}(\mathrm{x})=1 .
\end{gathered}
$$

Solution of linear equation system (5) for $\mathrm{x}<\mathrm{w}$ is as follows: 


$$
\begin{gathered}
\mathrm{p}^{*}{ }_{1}(\mathrm{x})=1 / 2, \\
\mathrm{p}_{2}{ }_{2}(\mathrm{x})=1 / 2 \mathrm{~F}(\mathrm{x}), \\
\mathrm{p}_{3}{ }_{3}(\mathrm{x})=1 / 2 \mathrm{R}(\mathrm{x}), \\
\mathrm{p}_{4}{ }_{4}(\mathrm{x})=0 .
\end{gathered}
$$

Whereas for $\mathrm{x} \geq \mathrm{w}$ the system of equations has the following form:

$$
\begin{gathered}
\mathrm{F}(\mathrm{w}) \mathrm{p}_{1}{ }^{*}(\mathrm{x})=\mathrm{p}_{2}{ }^{*}(\mathrm{x}), \\
\mathrm{R}(\mathrm{x}) \mathrm{p}_{1}{ }^{*}(\mathrm{x})=\mathrm{p}_{3}{ }^{*}(\mathrm{x}), \\
{[\mathrm{F}(\mathrm{x})-\mathrm{F}(\mathrm{w})] \mathrm{p}_{1}{ }^{*}(\mathrm{x})=\mathrm{p}_{4}{ }^{*}(\mathrm{x}),} \\
\mathrm{p}_{1}{ }^{*}(\mathrm{x})+\mathrm{p}_{2}{ }^{*}(\mathrm{x})+\mathrm{p}_{3}{ }^{*}(\mathrm{x})+\mathrm{p}_{4}{ }^{*}(\mathrm{x})=1 .
\end{gathered}
$$

Solution of linear equation system (7) for $\mathrm{x} \geq \mathrm{w}$ is as follows:

$$
\begin{gathered}
\mathrm{p}_{1}^{*}(\mathrm{x})=1 / 2, \\
\mathrm{p}_{2}^{*}(\mathrm{x})=1 / 2 \mathrm{~F}(\mathrm{w}), \\
\mathrm{p}_{3}^{*}(\mathrm{x})=1 / 2 \mathrm{R}(\mathrm{x}), \\
\mathrm{p}_{4}^{*}(\mathrm{x})=1 / 2(\mathrm{~F}(\mathrm{x})-\mathrm{F}(\mathrm{w})) .
\end{gathered}
$$

Taking into consideration that in the analyzed model of age-replacement it is assumed that $z_{1}=0$, hence criteria function (3) for $\mathrm{x}<\mathrm{w}$ has the following form:

$$
g(x)=\frac{z_{2} F(x) E T_{2}+z_{3} R(x) E T_{3}}{E T(x)+F(x) E T_{2}+R(x) E T_{3}},
$$

where ET(x) is the function determined by formula jest (2).

On the basis of (6) and (9), criteria function $g_{1}(x)$ for $x \leq w$ may now be presented in the following form:

$$
g_{1}(x)=\frac{B_{1} F(x)+C_{1}}{E T(x)+B F(x)+C},
$$

where coefficients $\mathrm{B}_{1}, \mathrm{~B}, \mathrm{C}_{1}$ and $\mathrm{C}$ are expressed as follows:

$$
\begin{gathered}
\mathrm{B}_{1}=\mathrm{ET}_{2} \mathrm{z}_{2}-\mathrm{ET}_{3} \mathrm{z}_{3}, \\
\mathrm{~B}=\mathrm{ET}_{2}-\mathrm{ET}_{3}, \\
\mathrm{C}_{1}=\mathrm{ET}_{3} \mathrm{z}_{3}, \\
\mathrm{C}=\mathrm{ET}_{3} .
\end{gathered}
$$

On the basis of (8) and (9), criteria function $\mathrm{g}(\mathrm{x})$ for $\mathrm{x}>\mathrm{w}$ may now be presented in the following form:

$$
g_{2}(x)=\frac{D_{1} F(x)+E_{1}}{E T(x)+D F(x)+E},
$$

where:

$$
\begin{gathered}
\mathrm{D}_{1}=\mathrm{ET}_{4} \mathrm{z}_{4}-\mathrm{ET}_{3} \mathrm{z}_{3}, \\
\mathrm{D}=\mathrm{ET}_{4}-\mathrm{ET}_{3}, \\
\mathrm{E}_{1}=\mathrm{F}(\mathrm{w})\left[\mathrm{ET}_{4} \mathrm{z}_{4}-\mathrm{ET}_{2} \mathrm{z}_{2}\right]+\mathrm{ET}_{3} \mathrm{z}_{3}, \\
\mathrm{E}=\mathrm{F}(\mathrm{w})\left[\mathrm{ET}_{4}-\mathrm{ET}_{2}\right]+\mathrm{ET}_{3} .
\end{gathered}
$$

The main problem analyzed in the paper is formulating the conditions for existence of the minimum function $\mathrm{g}(\mathrm{x})$ on condition $\mathrm{x} \geq 0$, determined as follows:

$$
\mathrm{g}(\mathrm{x})=\left\{\begin{array}{lll}
g_{1}(x), & \text { for } & x<w \\
g_{2}(x), & \text { for } & x \geq w
\end{array}\right.
$$

On the basis of formulas (10), (11), (12) and (13) it is concluded that criteria function $\mathrm{g}(\mathrm{x})$ depends on distribution of random variable $\mathrm{T}_{1}$, of the length of warranty period $\mathrm{w}$, unit costs $\mathrm{z}_{2}, \mathrm{z}_{3}$ and $\mathrm{z}_{4}$, mean times $\mathrm{ET}_{2}, \mathrm{ET}_{3}$ and $\mathrm{ET}_{4}$ of remaining at states $\mathrm{S}_{2}, \mathrm{~S}_{3}$ and $\mathrm{S}_{4}$ of the process.

\section{Criteria function properties}

Derivative of criteria functions (10) equals:

$$
g_{1}^{\prime}(x)=\frac{R(x)}{M_{1}^{2}(x)}\left\{B_{1} H(x)-C_{1}+\lambda(x)\left[B_{1} C-B C_{1}\right]\right\},
$$

where:

$$
\mathrm{M}_{1}(\mathrm{x})=\mathrm{ET}(\mathrm{x})+\mathrm{BF}(\mathrm{x})+\mathrm{C} \text { as well as } \mathrm{H}(\mathrm{x})=\mathrm{ET}(\mathrm{x}) \lambda(\mathrm{x})-\mathrm{F}(\mathrm{x}) .
$$

Denominator $\mathrm{M}_{1}(\mathrm{x})$ of first derivative of criteria function (10) is increasing function from $\mathrm{M}_{1}(0)=\mathrm{C}>0$ to $\mathrm{M}_{1}(\infty)=\mathrm{ET}_{1}+\mathrm{B}+\mathrm{C}$. Hence $M_{1}(x)>0$. Sign of derivative criteria function is the same as the sign of function $h_{1}(x)$, which may be written in the following form:

$$
\mathrm{h}_{1}(\mathrm{x})=\alpha_{1} \mathrm{H}(\mathrm{x})+\beta_{1}+\lambda(\mathrm{x}) \gamma_{1},
$$

where the following notations are assumed:

$$
\begin{gathered}
\alpha_{1}=\mathrm{B}_{1}, \\
\beta_{1}=-\mathrm{C}_{1}, \\
\gamma_{1}=\mathrm{B}_{1} \mathrm{C}-\mathrm{BC}_{1} .
\end{gathered}
$$

Coefficients $\alpha_{1}, \beta_{1}$ i $\gamma_{1}$ are expressed by formulas:

$$
\begin{gathered}
\alpha_{1}=\mathrm{ET}_{2} \mathrm{z}_{2}-\mathrm{ET}_{3} \mathrm{z}_{3}, \\
\beta_{1}=-\mathrm{ET}_{3} \mathrm{z}_{3}, \\
\gamma_{1}=\mathrm{ET}_{2} \mathrm{ET}_{3}\left(\mathrm{z}_{2}-\mathrm{z}_{3}\right) .
\end{gathered}
$$

By analogy, derivative of criteria (12) has the following form:

$$
g_{2}^{\prime}(x)=\frac{R(x)}{M_{2}^{2}(x)}\left\{D_{1} H(x)-E_{1}+\lambda(x)\left[D_{1} E-D E_{1}\right]\right\},
$$

where $\mathrm{M}_{2}(\mathrm{x})=\mathrm{ET}(\mathrm{x})+\mathrm{DF}(\mathrm{x})+\mathrm{E}$. 
Denominator $\mathrm{M}_{2}(\mathrm{x})$ of derivative of criteria function (12) is determined by the formula:

$$
\begin{gathered}
\mathrm{M}_{2}(\mathrm{x})=\mathrm{ET}(\mathrm{x})+\mathrm{F}(\mathrm{x})\left(\mathrm{ET}_{4}-\mathrm{ET}_{3}\right)+\mathrm{F}(\mathrm{w})\left(\mathrm{ET}_{4}-\mathrm{ET}_{2}\right)+\mathrm{ET}_{3}, \\
\mathrm{M}_{2}(\mathrm{x})=\mathrm{ET}(\mathrm{x})+\mathrm{F}(\mathrm{x}) \mathrm{ET}_{4}+\mathrm{F}(\mathrm{w})\left(\mathrm{ET}_{4}-\mathrm{ET}_{2}\right) .
\end{gathered}
$$

If $\mathrm{ET}_{4} \geq \mathrm{ET}_{2}$, then the inequality $\mathrm{M}_{2}(\mathrm{x})>0$ is true. Sign of derivative (16) of criteria function is the same as sign of function $h_{2}(x)$, which may be written as follows:

$$
\mathrm{h}_{2}(\mathrm{x})=\alpha_{2} \mathrm{H}(\mathrm{x})+\beta_{2}+\lambda(\mathrm{x}) \gamma_{2},
$$

where coefficients $\alpha_{2}, \beta_{2}$ and $\gamma_{2}$ are expressed by formulas:

$$
\begin{gathered}
\alpha_{2}=\mathrm{D}_{1}=\mathrm{ET}_{4} \mathrm{z}_{4}-\mathrm{ET}_{3} \mathrm{z}_{3}, \\
\beta_{2}=-\mathrm{E}_{1}=\mathrm{F}(\mathrm{w})\left[\mathrm{ET}_{4} \mathrm{z}_{4}-\mathrm{ET}_{2} \mathrm{z}_{2}\right]-\mathrm{ET}_{3} \mathrm{z}_{3}, \\
\gamma_{2}=\mathrm{D}_{1} \mathrm{E}-\mathrm{DE}_{1} .
\end{gathered}
$$

After transformations, coefficient $\gamma_{2}$ may be written as:

$\gamma_{2}=\mathrm{F}(\mathrm{w})\left[\mathrm{ET}_{2} \mathrm{ET}_{4}\left(\mathrm{z}_{4}-\mathrm{z}_{2}\right)+\mathrm{ET}_{2} \mathrm{ET}_{3}\left(\mathrm{z}_{2}-\mathrm{z}_{3}\right)+\mathrm{ET}_{3} \mathrm{ET}_{4}\left(\mathrm{z}_{3}-\mathrm{z}_{4}\right)\right]$

$+\mathrm{ET}_{3} \mathrm{ET}_{4}\left(\mathrm{z}_{4}-\mathrm{z}_{3}\right)$.

Lemma 1. If $\mathrm{ET}_{4}>\mathrm{ET}_{3}$ and $\mathrm{z}_{4} \geq \mathrm{z}_{3}$, then inequality $\gamma_{2}>0$ is true.

Proof. By grouping two final terms of the above total may be written as follows:

$$
\gamma_{2}=\mathrm{F}(\mathrm{w})\left[\mathrm{ET}_{2} \mathrm{ET}_{4}\left(\mathrm{z}_{4}-\mathrm{z}_{2}\right)+\mathrm{ET}_{2} \mathrm{ET}_{3}\left(\mathrm{z}_{2}-\mathrm{z}_{3}\right)\right]+\mathrm{R}(\mathrm{w}) \mathrm{ET}_{3} \mathrm{ET}_{4}\left(\mathrm{z}_{4}-\mathrm{z}_{3}\right) .
$$

Provided that $\mathrm{ET}_{4}>\mathrm{ET}_{3}$, we arrive at inequality:

$$
\gamma_{2}>\mathrm{F}(\mathrm{w}) \mathrm{ET}_{2} \mathrm{ET}_{3}\left[\left(\mathrm{z}_{4}-\mathrm{z}_{2}+\mathrm{z}_{2}-\mathrm{z}_{3}\right]+\mathrm{R}(\mathrm{w}) \mathrm{ET}_{3} \mathrm{ET}_{4}\left(\mathrm{z}_{4}-\mathrm{z}_{3}\right) .\right.
$$

Since $\mathrm{z}_{4} \geq \mathrm{z}_{3}$, we get:

$$
\gamma_{2}>\left(z_{4}-z_{3}\right) \mathrm{ET}_{3}\left[\mathrm{~F}(\mathrm{w}) \mathrm{ET}_{2}+\mathrm{R}(\mathrm{w}) \mathrm{ET}_{4}\right]
$$

which concludes the proof for lemma 1.

While formulating criteria of the existence of minimum function $\mathrm{g}(\mathrm{x})$, it is comfortable to examine function $\mathrm{h}(\mathrm{x})$ determined as follows:

$$
h(x)=h_{1}(x) \text { for } x \in<0, w>\text { as well as } h(x)=h_{2}(x) \text { for } x \in(w, \infty),
$$

where $\mathrm{h}_{\mathrm{i}}(\mathrm{x})=\alpha_{\mathrm{i}} \mathrm{H}(\mathrm{x})+\beta_{\mathrm{i}}+\gamma_{\mathrm{i}} \lambda(\mathrm{x})$, and $=1,2$.

A very important characteristic of function $\mathrm{h}(\mathrm{x})$ is determined by lemma 2.

Lemma 2. If unit cost of post-warranty repairs exceed unit costs of repairs during warranty period and post-warranty preventive replacement as well as for mean values, there is $\mathrm{ET}_{4} \geq \mathrm{ET}_{2}$, then $\mathrm{h}\left(\mathrm{w}^{+}\right)-\mathrm{h}(\mathrm{w})$ $\geq 0$, where $\mathrm{h}\left(\mathrm{w}^{+}\right)$is the right limit of function $\mathrm{h}(\mathrm{x})$ at point $\mathrm{x}=\mathrm{w}$.

Proof. We know that:

$$
\begin{gathered}
\alpha_{2}-\alpha_{1}=\mathrm{ET}_{4} \mathrm{z}_{4}-\mathrm{ET}_{2} \mathrm{z}_{2} \geq 0, \\
\beta_{2}-\beta_{1}=\mathrm{F}(\mathrm{w})\left[\mathrm{ET}_{4} \mathrm{z}_{4}-\mathrm{ET}_{2} \mathrm{z}_{2}\right] \geq 0
\end{gathered}
$$

Then result of subtraction:

$$
\begin{gathered}
\gamma_{2}-\gamma_{1}=\mathrm{F}(\mathrm{w})\left[\mathrm{ET}_{2} \mathrm{ET}_{4}\left(\mathrm{z}_{4}-\mathrm{z}_{2}\right)+\mathrm{ET}_{2} \mathrm{ET}_{3}\left(\mathrm{z}_{2}-\mathrm{z}_{3}\right)+\right. \\
\left.\mathrm{ET}_{3} \mathrm{ET}_{4}\left(\mathrm{z}_{3}-\mathrm{z}_{4}\right)\right]+\mathrm{ET}_{3} \mathrm{ET}_{4}\left(\mathrm{z}_{4}-\mathrm{z}_{3}\right)-\mathrm{ET}_{2} \mathrm{ET}_{3}\left(\mathrm{z}_{2}-\mathrm{z}_{3}\right)
\end{gathered}
$$

after grouping of final terms may be written in the following form:

$$
\begin{gathered}
\gamma_{2}-\gamma_{1}=\mathrm{F}(\mathrm{w}) \mathrm{ET}_{2} \mathrm{ET}_{4}\left(\mathrm{z}_{4}-\mathrm{z}_{2}\right)-\mathrm{R}(\mathrm{w}) \mathrm{ET}_{2} \mathrm{ET}_{3}\left(\mathrm{z}_{2}-\mathrm{z}_{3}\right)+ \\
\mathrm{R}(\mathrm{w}) \mathrm{ET}_{3} \mathrm{ET}_{4}\left(\mathrm{z}_{4}-\mathrm{z}_{3}\right) \\
\gamma_{2}-\gamma_{1}=\mathrm{F}(\mathrm{w}) \mathrm{ET}_{2} \mathrm{ET}_{4}\left(\mathrm{z}_{4}-\mathrm{z}_{2}\right)+\mathrm{R}(\mathrm{w}) \mathrm{ET}_{3}\left[\mathrm{ET}_{4}\left(\mathrm{z}_{4}-\mathrm{z}_{3}\right)-\right. \\
\left.\mathrm{ET}_{2}\left(\mathrm{z}_{2}-\mathrm{z}_{3}\right)\right]
\end{gathered}
$$

Provided that $\mathrm{ET}_{4} \geq \mathrm{ET}_{2}$ and $\mathrm{z}_{4} \geq \mathrm{z}_{3}$ for subtraction $\gamma_{2}-\gamma_{1}$ may be written as follows:

$$
\gamma_{2}-\gamma_{1} \geq \mathrm{F}(\mathrm{w}) \mathrm{ET}_{2} \mathrm{ET}_{4}\left(\mathrm{z}_{4}-\mathrm{z}_{2}\right)+\mathrm{R}(\mathrm{w}) \mathrm{ET}_{3} \mathrm{ET}_{2}\left(\mathrm{z}_{4}-\mathrm{z}_{2}\right),
$$

thus $\gamma_{2}-\gamma_{1} \geq 0$.

The final inequality as well as inequalities (17) and (18) prove the validity of the thesis of lemma 2.

\section{Conditions for the existence of minimum criteria function}

Examination of criteria function $\mathrm{g}(\mathrm{x})$ is considered with the following assumptions:

Z1. $\beta_{1}+\gamma_{1} \mathrm{f}\left(0^{+}\right)<0$,

$\mathrm{Z} 2$. Failure rate function $\lambda(\mathrm{t})$ of random variable $\mathrm{T}_{1}$ is non-decreasing

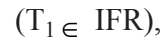

Z3. $\mathrm{ET}_{4}>\mathrm{ET}_{2}$,

Z4. $\mathrm{ET}_{4}>\mathrm{ET}_{3}$,

Z5. $\mathrm{z}_{4} \geq \mathrm{z}_{2}$,

Z6. $z_{4} \geq z_{3}$.

The first assumption is usually implemented while considering preventive replacements [9]. It is easy to observe that for numerous known probability distributions $\mathrm{f}\left(0^{+}\right)=0$ is valid. For example, for Weibull distribution and gamma distribution with increasing failure rate function this condition is valid. Therefore, if $\mathrm{f}\left(0^{+}\right)=0$, then in this paper the inequality $\beta_{1}=-\mathrm{ET}_{3} \mathrm{z}_{3}<0$ is always true. A very important assumption is the one claiming the failure rate function $\lambda(t)$ is nondecreasing $\left(\mathrm{T}_{1} \in \mathrm{IFR}\right)$.

\subsection{Examining criteria function in $\langle 0, w\rangle$ interval}

In examining function $\mathrm{g}(\mathrm{x})$ in $<0, \mathrm{w}>$ interval, $\mathrm{Z} 1$ and $\mathrm{Z} 2$ assumptions are implemented. Following is the examination of four cases for coefficients $\alpha_{1}, \gamma_{1}$.

Case 1. $\alpha_{1}>0, \gamma_{1}>0$

Function $h_{1}(x)$ increases in $<0, w>$ interval from value $h_{1}(0)=\beta_{1}+\gamma_{1}$ $\mathrm{f}\left(0^{+}\right)<0$ to value $h_{1}(w)$. Two cases are possible:

(A): $\mathrm{h}_{1}(\mathrm{w})>0$,

(B): $\mathrm{h}_{1}(\mathrm{w}) \leq 0$.

Case 2. $\alpha_{1}<0, \gamma_{1}<0$

Function $\mathrm{h}_{1}(\mathrm{x})$ decreases in $<0, \mathrm{w}>$ interval from value $\beta_{1}+\gamma_{1} \mathrm{f}\left(0^{+}\right)<$ 0 to value $h_{1}(w)$. Possible case (B).

Case 3. $\alpha_{1}>0, \gamma_{1}<0$

Derivative of function $h_{1}(x)$ is expressed by the formula:

$$
\mathrm{h}_{1}^{\prime}(\mathrm{x})=\lambda^{\prime}(\mathrm{x})\left[\alpha_{1} \operatorname{ET}(\mathrm{x})+\gamma_{1}\right] \text {. }
$$


Let $u(x)=\alpha_{1} \operatorname{ET}(x)+\gamma_{1}$, then $u(x)$ increases from $u(0)=\gamma_{1}<0$ to $\mathrm{u}(\mathrm{w})$. Two cases are possible:

(a): $\mathrm{u}(\mathrm{w}) \leq 0$, then $\mathrm{u}(\mathrm{x}) \leq 0$ for $\mathrm{x} \in<0, \mathrm{w}>$, hence $\mathrm{h}_{1}(\mathrm{x})$ is decreasing and case (B) occurs,

(b): $u(w)>0$, in this case function $u(x)$ changes the sign from, ,-" to „,". Function $\mathrm{u}(\mathrm{x})$, therefore, reaches minimum. Only cases (A) and (B) are possible.

Case 4. $\alpha_{1}<0, \gamma_{1}>0$

Function $\mathrm{u}(\mathrm{x})$ is decreasing from $\mathrm{u}(0)=\gamma_{1}>0$ to $\mathrm{u}(\mathrm{w})$. Depending on the sign of $\mathrm{u}(\mathrm{w})$, two cases are defined:

(c): $\mathrm{u}(\mathrm{w}) \geq 0$, then function $\mathrm{h}_{1}(\mathrm{x})$ is increasing for $\mathrm{x} \in<0, \mathrm{w}>$, therefore cases $(\mathrm{A})$ and $(\mathrm{B})$ are possible,

$(d): u(w)<0$, in this case, $u(x)$ changes the sign from ,,+" to ,-,", hence function $\mathrm{h}_{1}(\mathrm{x})$ at a point $\mathrm{x}_{0}$ reaches maximum. Formally, three of the following cases are possible:

(i): $\mathrm{h}_{1}\left(\mathrm{x}_{0}\right) \leq 0$, then $\mathrm{h}_{1}(\mathrm{w})<0$, case (B),

(ii): $\mathrm{h}_{1}\left(\mathrm{x}_{0}\right)>0$ and $\mathrm{h}_{1}(\mathrm{w}) \leq 0$,

(iii): $\mathrm{h}_{1}\left(\mathrm{x}_{0}\right)>0$ and $\mathrm{h}_{1}(\mathrm{w})>0$.

Cases (ii) and (iii) are discussed in the conclusion below.

Lemma 3. If $\alpha_{1}<0, \gamma_{1}>0$ and function $h_{1}(x)$ reaches maximum in point $\mathrm{x}_{0}$, then $\mathrm{h}_{1}\left(\mathrm{x}_{0}\right) \leq 0$.

Proof. Necessary and sufficient condition for existence of maximum function $\mathrm{h}_{1}(\mathrm{x})$ in $\left.<0, \mathrm{w}\right\rangle$ interval is the change of sign of derivative $\mathrm{h}_{1}{ }^{\prime}(\mathrm{x})$ at certain point $\mathrm{x}_{0}$, i.e. function $\mathrm{u}(\mathrm{x})$ from ,"+" to ,-,". For function $\mathrm{u}(\mathrm{x})$ we may write $\mathrm{u}\left(\mathrm{x}_{0}\right)=\alpha_{1} \operatorname{ET}\left(\mathrm{x}_{0}\right)+\gamma_{1}=0$, hence $\operatorname{ET}\left(\mathrm{x}_{0}\right)=-\gamma_{1} / \alpha_{1}$. The final equation is introduced to the formula for function $\mathrm{h}_{1}(\mathrm{x})$. Hence $\mathrm{h}_{1}\left(\mathrm{x}_{0}\right)=-\alpha_{1} \mathrm{~F}\left(\mathrm{x}_{0}\right)+\beta_{1}$. If $\mathrm{h}_{1}\left(\mathrm{x}_{0}\right)>0$, then $\mathrm{F}\left(\mathrm{x}_{0}\right)>\beta_{1} / \alpha_{1}$. Entering formulas (15) on the right side of the final inequality, we may write it in the following form:

$$
\mathrm{F}\left(\mathrm{x}_{0}\right)>1 /\left(1-\mathrm{ET}_{2} \mathrm{z}_{2} / \mathrm{ET}_{3} \mathrm{z}_{3}\right)
$$

The fact that $\alpha_{1}<0$ results in inequality $0<\left(\mathrm{ET}_{2} \mathrm{z}_{2}\right) /\left(\mathrm{ET}_{3} \mathrm{z}_{3}\right)<1$ being valid, hence finally, on the basis of (19) it is concluded that $\mathrm{F}\left(\mathrm{x}_{0}\right)>1$. Final inequality goes against the basic characteristic of the distribution function of random variable. Therefore, assumption $\mathrm{h}_{1}\left(\mathrm{x}_{0}\right)>0$ is not true in this proof, which concludes the proof for lemma 3 .

The thesis in lemma 3 implies that, for the introduced assumptions cases (ii) and (iii) fail to appear in deliberations of the paper.

\subsection{Examining criteria function in $(w, \infty)$ interval}

This section implements the following assumptions: Z2, Z3, Z4, $\mathrm{Z} 5$ and Z6. Implementing these assumptions allows for making use of the inequality $\alpha_{2}>0$ and $\gamma_{2}>0$. Paper (17) and lemma 1 suggest that function $\mathrm{h}_{2}(\mathrm{x})$ is increasing for $\mathrm{x} \in(\mathrm{w}, \infty)$. The cases considered are the following:

(C): $h_{2}(w) \geq 0$, then from the fact that function $h_{2}(x)$ is increasing implies that for each $\mathrm{x} \in(\mathrm{w}, \infty)$ function $\mathrm{g}(\mathrm{x})$ is increasing,

(D): $h_{2}(w)<0$ and $h_{2}(x)$ is increasing to do $h_{2}(\infty) \leq 0$, then $h_{2}(x) \leq 0$ for each $\mathrm{x} \in(\mathrm{w}, \infty)$. Function $\mathrm{g}(\mathrm{x})$ is decreasing in $(\mathrm{w}, \infty)$ interval, (E): $h_{2}(w)<0$ and $h_{2}(\infty)>0$. Function $h_{2}(x)$ is increasing and there is one change of sign from ,-, to ,," Criteria function $\mathrm{g}(\mathrm{x})$ has its minimum at certain point $\mathrm{x}_{0} \in(\mathrm{w}, \infty)$.

\subsection{Analysis of function for $x>0$}

For $\mathrm{x} \in(0, \mathrm{w}) \mathrm{w}$ two cases $(\mathrm{A})$ and $(\mathrm{B})$ were selected, while for $\mathrm{x}$ $\in(\mathrm{w}, \infty)$ three cases, (C), (D) and (E). Formally, in order to examine the course of criteria function $\mathrm{g}(\mathrm{x})$ for $\mathrm{x} \geq 0,6$ pairs of cases should be examined. However, a more detailed analysis of the characteristics of $\mathrm{g}(\mathrm{x})$ allows us to eliminate some pairs of cases.

Case (A, C): (A): $h_{1}(x)>0,(C): h_{2}(w) \geq 0$

On the basis of lemma 2 it was determined that in case $(A, C)$ it is enough to consider $(A): h_{1}(x)>0,(C): h_{2}(w)>0$. Therefore, one may arrive at a conclusion:

Conclusion 1. For case (A, C) criteria function $\mathrm{g}(\mathrm{x})$ reaches precisely one minimum at point $\mathrm{x}_{0} \in(0, \mathrm{w})$.

On the basis of lemma 2 it is concluded that pairs of cases (A, D) and $(\mathrm{A}, \mathrm{E})$ may not occur.

For pair $(B, C)$ : (B): $h_{1}(w) \leq 0,(C): h_{2}(w) \geq 0$ the following set is considered:

$$
\mathrm{K}=\left\{\mathrm{w}: \mathrm{h}_{1}(\mathrm{w})=0, \mathrm{~h}_{2}(\mathrm{w})=0\right\}
$$

The conclusion is evident:

Conclusion 2. If for case (B, C) set $\mathrm{K} \neq \varnothing$, then for any $\mathrm{x}_{0} \in \mathrm{K}$ function $\mathrm{g}(\mathrm{x})$ reaches minimum.

Implementing additional assumption into failure rate function leads to the following conclusion:

Conclusion 3. If failure rate function $\lambda(\mathrm{x})$ is increasing, then functions $\mathrm{h}_{1}(\mathrm{x})$ and $\mathrm{h}_{2}(\mathrm{x})$ are increasing and for $(\mathrm{B}, \mathrm{C})$ criteria function $\mathrm{g}(\mathrm{x})$ reaches exactly one minimum at point $\mathrm{x}_{0}=\mathrm{w}$.

For the pair (B, D) it is (B): $h_{1}(x) \leq 0,(D): h_{2}(w) \leq 0, h_{2}(\infty) \leq 0$. The fact that function $h_{2}(x)$ is non-decreasing as well as lemma 2 imply that it is enough to analyze the case when $\mathrm{h}_{1}(\mathrm{x})<0, \mathrm{~h}_{2}(\mathrm{w})<0$ i $\mathrm{h}_{2}(\infty) \leq 0$. Then the following conclusion is true:

Conclusion 4. For case (B, D) criteria function $\mathrm{g}(\mathrm{x})$ is decreasing.

For pair $(B, E)$ it is $(B): h_{1}(w) \leq 0,(E): h_{2}(w) \leq 0, h_{2}(\infty)>0$. Exceptional case when $h_{1}(w) \leq 0, h_{2}(w)=0$ was considered for case (B, C).

Conclusion 5. If $\mathrm{h}_{1}(\mathrm{w})<0, \mathrm{~h}_{2}(\mathrm{w})<0$ and $\mathrm{h}_{2}(\infty)>0$, then point $\mathrm{x}_{0} \in$ $(\mathrm{w}, \infty)$ exists at which function $\mathrm{g}(\mathrm{x})$ reaches minimum.

Conclusions 1, 2, 3, 4 and 5 include sufficient conditions for existence of minimum cost function $\mathrm{g}(\mathrm{x})$.

\section{Numerical example}

Example 1. In this example the optimization of criteria function is carried out for two distributions of random variables $T_{1}$. In the first one it is assumed the random variable $\mathrm{T}_{1}$ has Weibull distribution with probability density function in the form:

$$
f(t)=a b t^{b-1} \exp \left(-a t^{b}\right)
$$

for $\mathrm{t} \geq 0, \mathrm{a}>0, \mathrm{~b}>0$.

Time before failure $T_{1} \in$ IFR, if $b \geq 1$. The second distribution considered in this example is gamma distribution with density function in the form:

$$
f(x)=\frac{1}{\beta^{\alpha} \Gamma(\alpha)} x^{\alpha-1} e^{-x \beta},
$$

for $\mathrm{x} \geq 0, \alpha>0, \beta>0$, symbol $\Gamma(\alpha)$ denotes gamma function defined 
by the formula:

$$
\Gamma(\alpha)=\int_{0}^{\infty} x^{\alpha-1} e^{-x} d x
$$

If $\alpha \geq 1$, then time until failure $T_{1} \in$ IFR. In calculations the following parameter values were chosen:

$\mathrm{ET}_{2}=0.10, \mathrm{z}_{2}=1.2$,

$\mathrm{ET}_{3}=0.01, \mathrm{z}_{3}=0.7$,

$\mathrm{ET}_{4}=0.15, \mathrm{z}_{4}=1.5$.

In the example the warranty period considered is $\mathrm{w}=1$. For calculations, the following values of Weibull distribution parameters were chosen: $\mathrm{a}=0.4, \mathrm{~b}=2$. The values of gamma distribution parameters were set at $\alpha=3.63$ and $\beta=0.38$. Values of parameters $\alpha$ and $\beta$ of gamma distribution were selected so that for both considered times until failure the mean value of gamma distribution $\mathrm{ET}_{1}=\beta \alpha=1.4$ and distribution function value $\mathrm{F}(\mathrm{w})=0.33$. Graphs of function $\mathrm{g}(\mathrm{x})$ for both distributions are shown in figure 1.

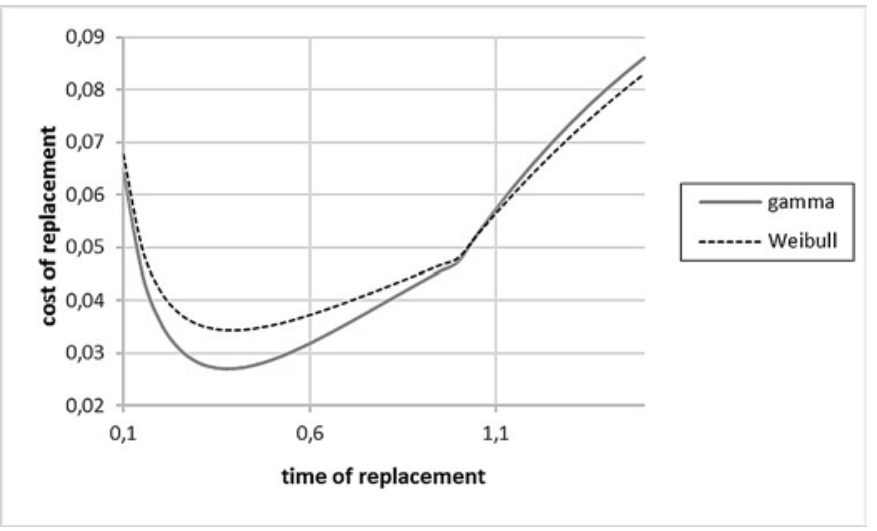

Fig. 1. Graphs of the cost of preventive replacement for gamma and Weibull distributions
Graphs of the functions of costs shown in the above figure are delineated for the same parameter values, they only differ in the type of probability distribution of random variable $\mathrm{T}$ meaning time until failure. An analysis of graphs shows that both criteria functions reach minimum values for approximate time moments. However, there are certain differences in optimal values for criteria function. The minimum value of criteria function for gamma distribution is lower than for Weibull distribution. It shows that the identification of the type of probability distribution for time until failure is important in maintenance tasks.

\section{Conclusions}

In the paper a criteria function was created to describe the cost of operation of maintenance system in the case of implementing age replacements according to the age of the elements (technical objects) with valid manufacturer's warranty as well as being non-repairable. Criteria for the existence of minimum cost for such replacements. It was demonstrated that, taking general assumptions into consideration, criteria function has one such minimum. Numeric example was shown, in which, for two distributions of time until failure the cost function reaches minimum value. It demonstrates that in practice there may be situations in which cutting of costs for preserving of maintenance systems is possible as a result of carrying out replacements of objects before expiration of warranty period.

\section{References}

1. Balcer Y, Sahin I. Replacement costs under warranty: cost moments and time variability. Operations Research, 1986; 34: 554-559, https:// doi.org/10.1287/opre.34.4.554.

2. Barlow R E, Proschan F. Mathematical Theory of Reliability. John Wiley \& Sons, 1965.

3. Berg H. A proof of optimality for age replacement policies. Journal Application. Probability, 1976; 13: 751-759, https://doi.org/10.1017/ S0021900200104413.

4. Berg H, Epstein B. Comparison of age, block and failure replacement policies. IEEE Transactions on Reliability, 1978; 27: 25-29, https:// doi.org/10.1109/TR.1978.5220230.

5. Blischke W R, Murthy D N P. Product warranty management I: A taxonomy for warranty policies. European Journal Operations Research, 992; 62: 127-148, https://doi.org/10.1016/0377-2217(92)90242-2.

6. Blischke W R, Murthy D N P. Product warranty management III: A review of mathematical models. European Journal Operations Research, 1992; 63: 1-34, https://doi.org/10.1016/0377-2217(92)90052-B.

7. Blischke W R, Murthy D N P. Warranty cost analysis. Marcel Dekker, 1994.

8. Blischke W R, Scheuer E H. Applications of renewal theory in analysis of the replacement warranty. Naval Research Logistics Quarterly, 1981; 28: 193-205, https://doi.org/10.1002/nav.3800280202.

9. Grabski F. Semi-markowskie modele niezawodności i eksploatacji [Semi-Markov models of reliability and maintenance]. Instytut Badań Systemowych PAN, 2002.

10. Ingram C R, Scheaffer R L. On consistent estimation of age replacement. Technometrics, 1976; 18: 213-219, https://doi. org/10.1080/00401706.1976.10489427.

11. Knopik L. Metoda wyboru efektywnej strategii eksploatacji obiektów technicznych [Method of selection of strategy of maintenance of technical objects]. Wydawnictwo Uniwersytetu Technologiczno-Przyrodniczego im. Jana i Jędrzeja Śniadeckich w Bydgoszczy, Rozprawy nr 145, 2010.

12. Osaki S S, Nakagawa T. A note on age replacement. IEEE Transactions on Reliability, 1975; 34: 147-150, https://doi.org/10.1109/ tr.1975.5215347.

13. Ritchken P H. Warranty policies for non-repairable items under risk aversion. IEEE Transactions on Reliability, 1985; 34: 147-150, https:// doi.org/10.1109/TR.1985.5221976. 
14. Yeh R H, Chen G Ch, Chen M Y. Optimal age-replacement policy for non-repairable products under renewing free-replacement warranty. IEEE Transactions on Reliability, 2005; 54: 92-97, https://doi.org/10.1109/TR.2004.841723.

\section{Leszek KNOPIK}

Faculty of Management

UTP University of Science and Technology

Fordońska Street 430, 85-890 Bydgoszcz, Poland

\section{Klaudiusz MIGAWA}

Faculty of Mechanical Engineering

UTP University of Science and Technology

Kaliskiego Street 7, 85-796 Bydgoszcz, Poland

E-mail: knopikl@utp.edu.pl, klaudiusz.migawa@utp.edu.pl 